\title{
Die skrifbeskouing van feministiese teoloë, in die besonder dié van Fiorenza, Brenner en Van Dijk- Hemmes - beoordeel in die lig van die gereformeerde teologie
}

\begin{abstract}
Authors:
Alta E. Swart ${ }^{1}$

Carel F.C. Coetzee ${ }^{2}$

Affiliations:

${ }^{1}$ Faculty of Human and Social Sciences, North-West University, South Africa

${ }^{2}$ Faculty of Theology, NorthWest University, South Africa

Correspondence to:

Alta Swart

Email:

altaswart@lantic.net

Postal address:

PO Box 344, Stella 8650,

South Africa

Dates:

Received: 18 June 2013

Accepted: 09 Sept. 2013

Published: 22 Oct. 2013

How to cite this article: Swart, A.E. \& Coetzee, C.F.C., 2013, 'Die skrifbeskouing van feministiese teoloë, in die besonder dié van Fiorenza, Brenner en Van Dijk-Hemmes - beoordeel in die lig van die gereformeerde teologie', In die Skriflig/In Luce Verbi 47(1), Art. \#1686, 9 pages. http://dx.doi.org/10.4102/ ids.v47i1.1686

\section{Note:}

This article was taken from the research results for a thesis which was handed in at the NWU in 2009. For a complete description of the view of Scripture of these theologians refer to this particular thesis (Swart 2009).
\end{abstract}

Read online:

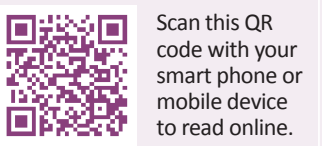

Dit wil voorkom asof die feministiese Skrifbeskouing op die beginsel van selektiewe Skrifgesag berus. Dit beteken dat slegs dié dele in die Bybel wat met die feministiese ideologie ooreenstem, as gesaghebbend aanvaar word. Dit is veral die sogenaamde androsentriese taalgebruik wat dit vir aanhangers van hierdie benadering moeilik maak om die hele Skrif as gesaghebbend te erken. Hermeneuties vertoon hierdie benadering groot ooreenkomste met die Postmodernisme, waarin geen vaste reëls bestaan om die betekenis van tekste te bepaal nie. Gesien in die lig van die gereformeerde teologie, soos veranker in die Woord en belydenisskrifte, vertoon die feministiese teologie ernstige leemtes. Die bydraes (Skrifbeskouing) van drie prominente feministiese teoloë - Fiorenza, Brenner en Van Dijk-Hemmes - word onder die loep geneem en teologies-krities geëvalueer ten einde hierdie leemtes uit te wys.

The view of Scripture according to feminist theologians, in particular that of Fiorenza, Brenner and Van Dijk-Hemmes - evaluated in the light of the reformed theology. It appears that the feminist view of Scripture is based on the principle of selective authority of the Scriptures, which means that only the parts of the Bible corresponding with the feminist ideology are accepted as authoritative. The use of androcentric language, in particular, makes it difficult for followers of feminism to accept the whole Bible as authoritative. Hermeneutically, their approach resembles Postmodernism, interpreting without any rules. Viewed from the paradigm of the reformed theology, which is anchored in Scripture and the articles of faith, feminist theology shows serious shortfalls. The contributions of three prominent feminist theologians - Fiorenza, Brenner and Van Dijk-Hemmes - are studied closely and evaluated critically in the light of the reformed theology, to underline these shortfalls.

\section{Inleiding}

Dit is onmoontlik om 'n kort, tiperende definisie van die feministiese teologie te gee, aangesien daar onder feministiese teoloë self uiteenlopende opvattings hieroor is. Na die bestudering van verskeie standpunte blyk die vernaamste kenmerke van die feministiese teologie egter die volgende te wees:

1. Dit is 'n bevrydingsteologie - dit wil die vrou bevry van 'n manlike metafoor vir God sowel as van die onderdrukking deur die man (Kassian 1992:225; Fiorenza 1979:49; Buitink-Heijblom 1992:12; Landman 1989:40).

2. Die vrou wil as gelyke met die man kompeteer op elke vlak van die samelewing, veral die kerk. Hulle verwerp tweeslagtigheid of het ernstige besware daarteen (Fiorenza 1986:28, 29; Oddie 1984:23).

3. Dit is 'n eensydige teologie wat net die standpunt van vroue wat feministiese oortuigings huldig, beklemtoon sonder dat daar na ander standpunte in hierdie verband geluister word (Halkes 1984:125).

4. Daar moet vasgestel of besluit word of God manlik of vroulik is (Russell 1987:19; Ruether 2002:3).

5. Deur selektiewe Skrifgebruik word slegs die betrokke uitgangspunt gestaaf. 'n Postmodernistiese benadering blyk duidelik uit hierdie werkwyse (Janse van Rensburg 2000:6, $7,9,11,26,32)$.

Drie internasionale feministiese teoloë se Skrifbeskouing word vervolgens kortliks bespreek, naamlik E.S. Fiorenza, A. Brenner en F. van Dijk-Hemmes. Hierdie teoloë se bydraes word in 
die lig van hulle internasionale invloed bespreek (Landman \& Van der Watt 2003:1679, 1680). Brenner en Van DijkHemmes is bekend vir die herleiding van tekste na die onderskeie manlike en vroulike oorspronge, terwyl Fiorenza vanuit die posisie van 'n kritiese historikus 'n feministiese hermeneutiese teorie ontwikkel het vir toepassing op bybelse bronne en ander ou tekste (Russell 1985:8).

Hierdie artikel poog om aan te dui dat die feministiese teologie se Skrifbeskouing fundamenteel van die gereformeerde teologie verskil en dat postmoderne hermeneutiek daarin 'n neerslag gevind het.

\section{Vertrekpunte}

Die artikel neem sy vertrekpunt vanuit die Calvinistiesgereformeerde tradisie. Dit impliseer onder andere die volgende:

1. Die Bybel is die ewige, altydgeldende Woord van God (Coetzee 1990:18, 19; Breed et al 2008:37 e.v.) wat Hy deur die inspirasie van die Heilige Gees tydgerig vir en deur mense laat boekstaaf het (2 Pet 1:21 en 2 Tim 3:16). ${ }^{1}$

2. Die gereformeerde standpunt ten opsigte van die Skrif soos aangedui in artikels 3 tot 7 van die Nederlandse Geloofsbelydenis (NGB), word hier gehuldig.

3. Die Bybel is die bron vir leer en lewe en is ook Christosentries (Breed et al. 2008:38).

4. Die eenheid in openbaring van die Ou en Nuwe Testament word gehandhaaf.

5. Hermeneutiek en interpretasie van die Skrif is slegs moontlik deur die verligting van die Heilige Gees, wat ook die Bybelskrywers geïnspireer het (2 Tim 3:16).

\section{Navorsingsmetodologie}

Hierdie artikel wil 'n bydrae maak op die gebied van die Dogmatiek. Die Skrifbeskouing van leidinggewende internasionale feministiese teoloë word bestudeer en vanuit die gereformeerde teologie beoordeel in die lig van die Skrif en die belydenisskrifte.

\section{Die Skrifbeskouing van Fiorenza, Van Dijk-Hemmes en Brenner}

Genoemde teoloë se Skrifbeskouing word bespreek onder die hoofde: Skrifgesag, Skrifkritiek, hermeneutiek en bybelse konteks.

\section{Skrifgesag}

Volgens Fiorenza word die vrou se ervaring gelykgestel met die Skrif en dit is belangriker as die teks van die Bybel (Fiorenza 1986:104). Brenner (Van Henten 1994:46) verklaar die Skrif sonder om dit wat die skrywer in gedagte gehad het, te herwin. Dit gaan oor die leser se interpretasie op die teks, in hierdie geval, in die feministiese styl.

1.Wanneer na God as Hy verwys word, word nie bedoel dat God manlik is nie. In hierdie artikel gaan dit oor die Skrifbeskouing van die feministiese teologie. Die Bybel verwys self op mensvormige wyse na God as manlike sowel as vroulik. In 'n artikel wat op die Godsleer van die feministiese teologie fokus, sou daar wel breedvoerig aan die synsontologie van God aandag gegee moes word.
Die Bybel word as 'n politieke dokument verstaan wat sekere belangegroepe, veral die man, bevoordeel. Gesag word slegs aan teksgedeeltes toegeken wat vir die feministiese teologie aanvaarbaar is (Fiorenza 1986:9). Brenner beskou Jeremia byvoorbeeld as fiktief (Brenner 2004b:257) en Van DijkHemmes betwyfel die betroubaarheid van die Skrif, omdat die mondelinge tradisies vroue uitsluit (Van Dijk-Hemmes 1993:19). Die resultaat hiervan is 'n verskraalde kanoniek. Fiorenza gebruik die Bybel as 'n wapen teen Skrifgesag, met ander woorde teen die Bybel self (Fiorenza 1999:28).

Fiorenza neem Galasiërs 3:28 (1953-vertaling) as die uitgangspunt vir vrouebediening: 'Daar is nie meer Jood of Griek nie, daar is nie meer slaaf of vryman nie, daar is nie meer man of vrou nie; want julle is almal een in Christus Jesus.' Dit word geïnterpreteer asof daar nie 'n bybelse onderskeid tussen die geslagte is nie. Fiorenza gebruik soortgelyke tekste om die feministiese ideaal te beredeneer en om patriargale tekste te beoordeel, asook om te besluit oor die opname van tekste in die Bybel (Fiorenza 1986:81).

Fiorenza $(1985: 39,40)$ meen dat die Bybel as patriargale geskrif die man bevoordeel. Die onderdrukte stemme van die vrou binne die teks, wat om bevryding roep, moet uitgebrei word. Omdat die betekenis van die bybelse teks by die leser aangepas kan word, moet vroue dit aanpas - sodoende hang die interpretasie van die Bybel dus af van wat vroue voor gevra het. Die Bybel is nie 'n geslote kanon nie, maar moet voortdurend aanpas by die tyd, omstandighede en behoeftes van die leser.

Feministiese teoloë voer aan dat die Bybel deur mans geskryf is en dat dit die patriargale mag en onderdrukking wettig, want dit maak van God 'n man (Fiorenza 1986:9). Sommige feministe soos Mary Daly (1983:43-48, 52, 99), wil afstand doen van die Bybel en die bybelse godsdiens, maar Fiorenza (1986:10) vra dat die bybelse godsdiens weer opgeëis moet word as vroue se eie erfgoed, omdat hulle krag daarin lê, maar dan met die nodige wysigings in taalgebruik.

Fiorenza (1985:86) dui aan dat Efesiërs 5:21-23 gebruik word om vroue se onderdanigheid aan hulle mans te beskryf, maar sy ignoreer die raad oor vaders, kinders, meesters en slawe, wat ' $n$ integrale deel van die oorspronklike perikoop vorm. Volgens haar beveel die teks by implikasie onderdanigheid van vroue aan hulle mans aan en die man word met Christus geïdentifiseer (Fiorenza 1985:58). Van Dijk-Hemmes (1994:919 en Brenner (2004b:256, 257) beskou ook die Ou Testament as 'n politieke dokument wat die ideologieë van sekere belangegroepe bevorder.

\section{Skrifkritiek}

Skrifkritiek skaal die goddelike gesag van die Bybel af en beklemtoon die menslike gesag van die Bybel ten koste van die goddelike karakter. Die Heilige Gees as die eerste skrywer van die Bybel word hierdeur geminimaliseer. Die eenheid van die Skrif word verwerp en elke Bybelboek word as ' $n$ losstaande eenheid binne ' $n$ bundel beskou en buite 
konteks hanteer en bestudeer (Jordaan 1991:8). Die radikale Skrifkritiek ${ }^{2}$ ontken dat die Bybel 'n boodskap vir vandag het (Jordaan 1991:8, 9).

\section{Skrifkritiese skrifhantering deur Fiorenza, Brenner en Van Dijk-Hemmes \\ Fiorenza}

Volgens Fiorenza (2001:9) het mans die Bybel geskryf, geïnspireer en as kanoniek aanvaar en daarom is dit vir die (feministiese) vrou onaanvaarbaar. Dit is boonop in androsentriese taal geskryf (Fiorenza 1985:130), wat beteken dat beelde soos Vader en Seun en voornaamwoorde soos hy en hom ten opsigte van God gebruik word. Omdat mans in die kerk die Bybel misbruik soos dit hulle pas, word die Bybel nie deur die feministe as 'n gesaghebbende bron beskou nie, maar slegs as 'n hulpbron vir vroue in hulle bevrydingstryd. Die Bybel is daarom nie die geskikte kanon nie, maar moet voortdurend aangepas word om by die feministiese standpunt te pas.

Fiorenza (2001:9) sê dat 'n kritiese feministiese benadering tot die Skrif nie binne die grense van die kanon kan bly nie, omdat sommige geskrifte as kanoniek opgeneem en ander ongewenstes as apokrief uitgelaat is. Dit maak die Bybel eksklusief. Die Bybel as die enigste woord van God, het in die patriargale gemeenskap en kerk baie onderdrukking veroorsaak (Fiorenza 2001:9).

Fiorenza $(1992: 54,55)$ is 'n voorstander van bybelse stories vanuit ' $n$ ander perspektief, asook van die uitbreiding van bevrydende stemme binne die teks. Die stiltes van die onbelangrike vrouefigure moet daardeur verbreek word.

Sy konsentreer op 'n kritiese evaluering van bybelse tekste, gekombineer met die verklaring daarvan. NuweTestamentiese tekste wat handel oor 'n tyd waarin menslikheid herstel en vrygemaak is, glo dat die 'woord van God' daarin nie vroue kan skade doen en agterdog kan wek nie. Voorts word slegs historiese eksegese en moderne interpretasies gebruik en gelees. $\mathrm{Na}$ 'n versigtige ondersoek en inklusiewe vertaling mag dan slegs bybelse tekste wat die dissipelskap van gelykes bevestig, in die liturgie aangebied en aanvaar word (Fiorenza 1985:125-135).

In Rhetoric and ethic wil Fiorenza (1999:22) die bybelse wetenskap in 'n krities-verklarende praktyk vir bevryding omskep. Fiorenza (1999:27) beweer dat 'n historiese leeswyse aan die teks gee wat dit toekom, naamlik om die moontlike historiese betekenis te handhaaf teenoor latere dogmatiese toeëiening. Dit maak die vereenselwiging van die teks met die eie ondervinding moeiliker en hou die prikkeling van die oorspronklike teks lewendig deur die eie veronderstellings en opvattings.

Geen interpretasie is heeltemal onpartydig nie, maar dit is aan een of ander ideologie gekoppel (Fiorenza 1999:92). Vroue kan dus ook - soos mans - die manuskrip van die moet word.
Bybel verander om dit van manlike oorheersing te suiwer, met die gepaardgaande agterdog as reaksie daarop.

Die boek, In memory of her (Fiorenza 1983-1994:29), verteenwoordig die paradigma van die teoloë wat tot die feministiese histories-kritiese eksegese van die Nuwe Testament bygedra het. Feministiese kritiek maak die leser bewus van die behoefte om die verlede te ken, sonder verabsolutering en om veranderlikes soos sosiale, politieke en teologiese skikkings met historiese geskrifte in ag te neem (Fiorenza 1996:vii-ix).

Fiorenza (1996:vii-ix) het na 'n ander bybelse metafoor en retoriese beeld gesoek wat bemiddelend kon optree tussen die feministiese alternatiewe, naamlik die kerk as tuiste, of die uittog na 'n nuwe vrygemaakte tuiste. Daar moet ruimte vir bespreking van die verskillende feministiese teoretiese uitsprake en praktiese strategieë wees. Deur die besware van feministe van kleur teen dié van die patriargie, wat verstaan word as geslagsonderdrukking van alle vroue deur mans van alle klasse, probeer Fiorenza 'n nuwe bybelse beeld skep waarin die uitdrukking woman-church die verbinding tussen die vrou en die kerk beskryf.

Vir Fiorenza $(2000: 155,156)$ is die interpretasie van die Bybel endemies - dus beperk tot 'n sekere groep. Die illusie van objektiwiteit ten gunste van die besef dat alle interpretasie bepaal word deur die vrae van die kontemporêre verklaarder, word daarom verwerp. Daardeur word erken dat alle interpretasie noodwendig hermeneutiek insluit, selfs dié wat doelbewus na slegs die feite uit die verlede soek wat by die gevraagde vrae pas. 'n Radikale paradigmaskuif vanaf dominansie na radikale gelykheid is hier ter sprake. Die Bybel word ook nie as 'n geslote kanon gesien nie, maar moet voortdurend aanpas by veranderende situasies en die interpretasie daarvan moet emansiperend wees.

\section{Brenner en Van Dijk-Hemmes}

Brenner (1996:53) en Van Dijk-Hemmes beskryf God as onregverdig. Miriam word byvoorbeeld oënskynlik onregverdig gestraf, terwyl Aäron ongestraf bly omdat God aan sy kant is. Hulle beswaar is dat vroue in die Bybel as afhanklik uitgebeeld word en dat sterk figurasie deur vroue, byvoorbeeld Ester, besoedel word deur die manlike invloed. Mans misbruik vroue en vroue se verkeerde optrede (bv. dié van Ohola en Oholiba in Eseg 23:4) word veel meer beklemtoon as dié van mans (bv. die towerheks van Endor in 1 Sam 28:7).

Brenner en Van Dijk-Hemmes (1993:114) wil die tekste van die Ou Testament na die geslagsoorsprong lei in 'n poging om vroulike stemme in die bybelse tekste te kry. Brenner (1993a:13) sê in hierdie verband dat die doel met On gendering texts is om ' $n$ bydrae te maak tot leesalternatiewe - en wel in die feministiese styl. Hulle poog om aan die vroulike stem meer gesag te gee as die tradisionele stem van die skrywer.

Brenner (1996:23) vind dit ontstellend dat die profetiese literatuur metafore gebruik waarin mans uitgebeeld word 
as heilig en toegewyd, maar vroue as troueloos en wêrelds. Sy ondervind dat God in die Ou Testament teen die vrou diskrimineer: vroue mag nie openbare leiers of sprekers wees nie en in Amos 4:1 word hulle selfs met koeie vergelyk.

Die smaad van die dogters van Sion in Jesaja 3:24-4:1 word deur Brenner (2004a:24) beskou as die smaad van ongetroud wees, of om sonder manlike beskerming te wees. Sy dui aan dat 'n vrou wat in die patriargale bestel nie behoorlik aan 'n huishouding verbind is met 'n man as die hoof nie, buite die sosiaal-aanvaarbare grense val.

Brenner (2004a:26, 27) verduidelik dat in Hosea, Jeremia, Esegiël, Sagaria en Jesaja gereeld metafore gebruik word van 'n heilige eggenoot teenoor 'n ontroue, menslike vrou: YHWH/God is altyd die getroue, liefdevolle man, terwyl die goddelose mense van die stede altyd die ontroue, egbrekende vrou is. Dit versterk die gedagte van die positiewe, verhewe manlike teenoor die negatiewe, minderwaardige vroulike geslag. Brenner (2004b:258) beskou dit as diskriminasie teen die vroulike geslag, wat vir baie vroulike lesers van die Bybel problematies kan wees.

Die erotiese metafoor in Jeremia word deur Brenner (2004b:259, 260) as pornografies geëvalueer, want dit stimuleer die seksuele fantasie met die doel om die vroulike seksualiteit as boos uit te beeld en om die gehoor skaam te maak. Die metafoor is skokkend en blatant en kom daarop neer dat pornografie gebruik word om godsdienstige en politieke hervorming teweeg te bring. Die dierebeelde wat vir die vroue in Jesaja gebruik word, is vir Brenner (2004b:263) ook onaanvaarbaar, veral omdat dit diere is wat bekend is vir negatiewe kenmerke, soos donkies en kamele. Die vrou word daardeur doelbewus afgekraak in vergelyking met die man en die manlike God.

Spreuke 1-9 laat Brenner (1993b:116, 117) tot die gevolgtrekking kom dat daar 'n vrou aan die woord is, omdat Spreuke afgesluit word met die gedig oor die vrou en moeder (Spr 31) wat in 'n bevoorregte posisie staan. Sy vertolk die teenwoordigheid van die Wysheid, veral in hoofstuk 8, as vroulik en dat Spreuke 1-9 daarom ook uit die mond van 'n vrou en moeder kan kom (Brenner \& Van Dijk-Hemmes 1993:121). Brenner interpreteer die laaste deel van Spreuke 31 as 'n moeder se onderwysing aan haar dogter en derhalwe as vroulike literatuur (Brenner \& Van Dijk-Hemmes 1993:127, 128).

Die raaisel in Spreuke 30:18-20 is vir Brenner problematies, want sy sien al die beelde as gewelddadig en beskou daarom die laaste beeld as seksuele beheer van 'n man oor 'n vrou. Sy maak beswaar teen die universaliteit van hierdie beeld (Brenner \& Van Dijk-Hemmes 1993:159, 160).

Van Dijk-Hemmes (1993:24) ondersteun Schüssler-Fiorenza in die soeke na vroulike skrywers in die Bybel, sodat korrektiewe gevind kan word vir die opvatting dat die Bybel uitsluitlik die werk van manlike skrywers is. Die Bybel moet derhalwe op feministiese wyse gewysig word.
Aangaande Hosea merk Van Dijk-Hemmes op dat die eensydigheid van die manlike interpretasies van die Bybel vir 'n eensydig-feministiese teenwig vra (Bekkenkamp et al. 1989:128). Sy is ontevrede met die inhoud van die Bybel en wil vanuit die feministiese oortuiging alles wat met geslag verband hou, bevraagteken en verander.

Van Dijk-Hemmes (2004:245, 246) wil Hosea 1-3 vanuit 'n feministiese hoek lees, in teenstelling daarmee dat baie manlike verklaarders die huweliksmetafoor in Hosea sien as 'n gelykenis van heilige genade en vergifnis. Sy wil 'n voorgeskrewe uitleg van die Skrif uitdaag deur 'n vroulike uitleg van dieselfde stuk (Van Dijk-Hemmes 1993:107).

Die feit dat 'n vrou soos Ester die hoofkarakter in 'n boek is, veronderstel volgens Van Dijk-Hemmes (1993:31) nie noodwendig vroulike outeurskap nie. Ester pas naamlik perfek in die rol van ideale vroulikheid soos dit deur mans veronderstel word. Van Dijk-Hemmes (1993:37) aanvaar ook nie sonder meer dat die loflied wat die vroue gesing het om Saul en Dawid te vereer, juis so deur die vroue gesing is nie. Sy beklemtoon dit dat 'n manlike invloed deur die mondelinge oorlewering kon ingesluip het.

Aangaande Ohola en Oholiba in Esegiël 23 sê Van DijkHemmes (2004:252-254) en Brenner en Van Dijk-Hemmes (1993:173-176) dat die susters op 'n pornografiese wyse beskryf en in die openbaar verneder en verkleineer word, om te beklemtoon dat hulle seksualiteit onder manlike beheer en in manlike besit moet wees. Die regverdige manne wat in vers 45 geroep word om oor hierdie vroue te oordeel, is vir Van Dijk-Hemmes 'n teken dat die Bybel ten gunste van mans geskryf is en as waarskuwing vir vroue dien. Die laaste verse is waarskynlik bygevoeg om manlike lesers te pas.

Van Dijk-Hemmes (1993:62, 63) wys daarop dat daar in die Bybel van slegs enkele profetesse sprake is, naamlik Miriam, Debora, Hulda, Noadja en die naamlose vrou van Jesaja. Sy voer aan dat aangesien daar ongenoemde profete in Israel was, die afleiding gemaak kan word dat sommige van hulle ook profetesse was. Van Dijk-Hemmes (1993:70) het beswaar daarteen dat die towerheks van Endor, 'n vrou, die enigste heks is wat genoem word, terwyl daar geen verwysing is na die manlike hekse nie.

Volgens Brenner en Fontaine (1997:77) lees Brenner en Van Dijk-Hemmes tussen die lyne van die bybelse verhaal om materiaal te vind wat op 'n positiewe of ingeligte manier met vroue of hulle aangeleenthede handel. Sulke tekste word as double voiced gekenmerk en impliseer dat vrouestemme gehoor mag word.

In die voorwoord tot On gendering texts, naamlik 'Female and male voices in the Hebrew Bible' (Brenner \& Van Dijk-Hemmes 1993), verduidelik Mieke Bal (1993:ix) dat die skrywers van hierdie publikasie nie meer in die inspirasie van die Heilige Gees by die skryf van die Bybel glo nie. Brenner (1993a:3) meen ook dat enige vroulike tekste in die Bybel in die manlike tekste ingesluit is en deur manlike redigering en 
redaksionele aktiwiteite omraam is. Vroue se literêre tradisies is hoofsaaklik mondeling oorgedra, terwyl die manlike tradisies aangeteken is. Brenner (1993a:8) wys daarop dat die interpretasie van geslag in 'n teks grootliks afhang van die leser se geslag.

Brenner sowel as Van Dijk-Hemmes (1993:73, 74) betwis Salomo se outeurskap van Hooglied. Die feit dat daar so dikwels 'n vrou aan die woord is en die feit dat daar so baie vroulike emosies uitgedruk word, dui volgens hulle op 'n vroulike skrywer van Hooglied.

\section{Hermeneutiek}

Hermeneutiek soos in die gereformeerde teologie verstaan word, formuleer die beginsels waarvolgens die Skrif verklaar moet word en behels dus ook die wyse waarop die Skrif geïnterpreteer word. 'n Bepaalde hermeneutiek kan daarom ook nie van 'n bepaalde Skrifbeskouing losgemaak word nie. Volgens Breed et al. (2008:40) moet daar onderskeid gemaak word tussen dit wat in die Bybel geskryf staan en die leser se eie verklaring daarvan. Dit wat in die Bybel geopenbaar word, staan vas, maar die leser se verklaring moet altyd aan die Bybel gemeet word.

Fiorenza (1983-1984:32) dui byvoorbeeld aan dat die leser die betekenis van die teks bepaal, met die gevolg dat dieselfde teks meer as een betekenis kan hê. Volgens Brenner en Van Dijk-Hemmes gaan die interpretasie van 'n teks daarom nie oor wat die skrywer wil sê nie, maar oor hoe die leser dit interpreteer. Die interpretasie word onder andere bepaal deur die leser se geslag. Fiorenza (1983-1984:35) voer voorts aan dat die teks herinterpreteer word soos dit die leser pas.

In die feministiese benadering is daar nie vaste hermeneutiese reëls nie, maar vroue se stryd om bevryding is die kriterium vir interpretasie. Fiorenza benadruk dit dat vroue die Skrif moet verklaar en aanpas soos dit hulle pas (Clifford 2001:61). Brenner (1993a:2) en Van Dijk-Hemmes verwerp manlike verklaarders van die Bybel en aanvaar slegs vroulike verklarings. Hulle handhaaf 'n suspisieuse hermeneutiek wat daardeur gekenmerk word dat hulle nie glo dat die Heilige Gees die Bybel geïnspireer het nie, maar dat dit deur mans geïnspireer en verklaar is (Clifford 2001:61). Hulle wil gevolglik die tekste uithaal wat in stryd met die feministiese teologie is (Fiorenza 1985:39, 40). Hulle hermeneutiek wil ook die lyding van die vrou in die verlede onthou en dit gebruik om die Skrif van manlike onderdrukking te bevry (Fiorenza 1985:40). Vir Fiorenza (1996:vii-ix) is die vrouekerk nodig om die betrokke tekste te aanvaar of te verwerp, omdat die ervaring van vroue so belangrik is.

Fiorenza (1983-1984:32) is van mening dat die interpretasie van die Bybel emansiperend vir die onderdrukte vrou moet wees. Brenner (2004b:256, 257) en Van Dijk-Hemmes (1994:9-19) sien op hulle beurt die Bybel as 'n politieke dokument wat die belange van sekere belangegroepe (die man) bevoordeel. Hulle wil daarom die Bybel sodanig interpreteer dat hulle dit kan verander om die feministiese idee te pas.

\section{Postmoderne hermeneutiek by Fiorenza, Brenner en Van} Dijk-Hemmes

By die postmodernistiese hermeneutiek bepaal die leser die betekenis van die teks (Horton 2000:68; Adam 1995:18). Daar is nie vaste reëls nie (Janse van Rensburg 2000:2). Die waarheid moet gemanipuleer word om die mens se doel te bereik (Erickson 2001:194).

Fiorenza (1983-1984:32) glo dat 'n feministiese hermeneutiek die elemente binne alle bybelse tradisies moet ontbloot en dit verwerp wat in die naam van God vervreemding, geweld, patriargale onderdrukking en die verwydering van die vrou uit die histories-teologiese bewustheid goedpraat. 'n Christelike bevrydingsteologie moet nie die Bybel probeer beskerm teen feministiese kritiek nie, maar moet erken dat die oorsprong van vroue se krag ook die oorsprong van hulle onderdrukking is. Vroue moet verby die androsentriese bybelse teks kan beweeg na die sosiohistoriese teks (Fiorenza 1983-1984:35). Fiorenza (2010:392) meen dat die leser die interpretasie bepaal en dat daar gevolglik geen regte of verkeerde interpretasie kan wees nie. Hierdeur verkry 'n teks baie betekenisse. Omdat die hermeneuties-postmoderne paradigma nie al die onsekerhede kan hanteer nie, moet daar ook'n eties-politiese paradigma wees wat met 'n geskakeerde publiek kan kommunikeer.

Volgens Fiorenza (1986:19) is 'n kritiese feministiese hermeneutiek ' $n$ aansporing vir die Bybelwetenskap sowel as die Christelike etiek om 'n kritiese evaluasiehermeneutiek te ontwikkel wat noukeuriger op die polities-onderdrukkende invloed van die Bybel kan ingaan, omdat erken word dat dit in die Christelike teologiese denke eerstens om geregtigheid gaan. Fiorenza (1986:30) twyfel of die Bybel, as produk van 'n patriargale kultuur, nog as die heilige Skrif vir die vrouekerk kan geld, indien die ervaring van vroue in hulle stryd om bevryding aanvaar word as 'n gesaghebbende hermeneutiese kriterium.

Vir Brenner beteken teksverklaring nie noodwendig om dit wat die skrywer in gedagte gehad het, te herwin nie (Van Henten 1994:46). Interpretasie is 'n leser se reaksie op 'n teks en dieselfde geld vir die aanwending van 'n intertekstuele leeswyse. Die leser verbind verskillende tekste en herken en interpreteer die verhoudings tussen hulle - ook wat die Bybel betref.

\section{Bybelse konteks}

Fiorenza wys op die krities-politieke betekenis van die feministiese Bybelinterpretasie. Sy (Fiorenza 1986:32) beklemtoon die feit dat die Bybel deur mans in androsentriese taal en in ' $n$ patriargale tyd geskryf is en dat dit daarom vir feministiese teoloë en die vrouekerk onaanvaarbaar is. Die patriargale siening oor God in die Skrif moet verander word omdat dit mans bevoordeel en vroue benadeel. Gevolglik kan slegs dié tekste wat nie deur androsentrisme besmet is nie, as normatief aanvaar word. Die Bybel is hiervolgens nie meer 'n gesaghebbende bron nie, maar slegs 'n hulpbron vir die bevrydingstryd van vroue (Fiorenza 1986:36). Manlike 
Bybelskrywers bedreig die feministiese lesers en daarom bevraagteken hierdie lesers die inspirasie van die Heilige Gees. In navolging van die feministiese teologie is Fiorenza (1985:85) van mening dat die Bybel deur manlike leiers in die kerk misbruik word, omdat hulle slegs daardie dele in die kerk lees wat hulle pas en die patriargale boodskap van die kerk oordra.

Die toepassing van geslag in die teologie impliseer dat geslagsneutraliteit binne die teologie bevraagteken word (Van Dijk-Hemmes 1994:12). Omdat dit hoofsaaklik oor manlike persone gaan wie se geslag hulle werk beïnvloed, is geslag nie neutraal nie en mans se geslag strek hulle tot voordeel. Die feministiese teologie vergelyk die lyding van vroue met die lyding van Jesus Christus.

\section{Beoordeling Skrifgesag}

Indien van die standpunt uitgegaan word dat die Bybel die Woord van God is, kan geen mens se geskiedenis of ondervinding daarmee gelykgestel word nie (Coetzee 1990:18). Die gereformeerde standpunt is dat God Homself aan die mens in die Skrif openbaar, dat Hy sy Wil openbaar en dat Hy die weg tot die Ewige Lewe is (Coetzee 1990:21; NGB art 2, 5, 7).

Die evangelie verkondig God en wie weier om na die Woord te luister, weier om na God te luister en verwerp eintlik albei (Booyens 1980:48). Artikel 7 van die NGB sê duidelik dat die Bybel die wil van God volkome bevat asook alles wat ' $n$ mens nodig het vir jou saligheid. Dit is verbode om iets van die Woord weg te neem of daaraan toe te voeg (Feenstra 1950:72-80). Vanuit die gereformeerde standpunt is dit dus duidelik dat geen mens - hetsy manlik of vroulik - se geskiedenis aan die Woord gelykgestel kan word nie.

Die sola Scriptura-beginsel was en is een van die sentrale beginsels van die Hervorming. Hieronder word verstaan dat die Skrif gesagvol en die hoogste norm is (vgl. onder andere Schwertley s.a.:5-22). Wanneer 'n mens jou op ander faktore beroep, byvoorbeeld die geskiedenis van die vrou, word iets of iemand buite God as bron van heil aanvaar. Die geskiedenis het wel openbaringswaarde (vgl. art 1 NGB), maar het nie kanonieke gesag nie. Indien iets anders as die absolute waarheid naas die Skrif aanvaar word, is dit eiewillige godsdiens wat vol van menslike leuens is (Booyens 1980:57). Teoloë wat net sekere dele van die Bybel aanvaar, verwerp dus inderwaarheid eintlik die Woord sowel as God, die Skrywer van die Woord.

Wanneer die Bybel as 'n dokument hanteer word wat vroue se belange bevorder, word 'n eiewillige verklaring van die Bybel geskep om by 'n sekere standpunt aan te pas. Sodanige benadering aanvaar nie die hele Bybel as die Woord van God nie, maar lees en verander dit om by sekere uitgangspunte te pas. Hierdie postmoderne beginsel dat die leser bepaal hoe ' $n$ teks geïnterpreteer moet word (Horton 2000:68), weerspreek die gereformeerde beginsel dat die Bybel die Woord van God is (Coetzee 1990:18, 19; Breed et al. 2008:37, 38).
In hoofstuk 7 van sy Institusie sê Calvyn (1967:52-54) dat die gesag van die Skrif deur die getuienis van die Heilige Gees vasstaan. Dit beteken dat daar nooit net aan sekere dele van die Skrif, wat by die mens se oortuigings pas, goddelike gesag gegee kan word nie. Die Bybel kan derhalwe nie by die moderne vrou aanpas nie. Die inspirasie van die Heilige Gees word ontken wanneer die manlike skrywers daarvan beskuldig word dat hulle doelbewus sekere dinge wat vroue gedoen het, uit die Bybel weggelaat het (Coetzee 1990:19-20; Feenstra 1978:12-18; Breed et al. 2008:42). Vergelykings in die Bybel impliseer ook nie dat die man Christus is nie, maar word ter verduideliking gebruik. Die vergelyking word dikwels deur feministiese teoloë misgekyk.

\section{Skrifkritiek}

Skrifkritiek is die wetenskap wat veral sedert die negentiende eeu in die teologie inslag gevind het. Ten diepste gaan dit in Skrifkritiek oor die verhouding tussen die wetenskap en die Heilige Skrif. Skrifkritiek gaan volgens Berkouwer (s.a.:8) uit van die voorrang van die wetenskap en 'n grenslose vertroue in die mag van die wetenskap. Dit gebeur tot so ' $n$ mate dat die karakter van die openbaring in die gedrang kom deurdat Skrifkritiek en die leer van die onfeilbaarheid van die Skrif mekaar uitsluit (Berkouwer s.a.:13). Dieselfde geld ook vir die inspirasie van die Skrif teenoor die historiese verstaan van die Skrif (Berkouwer s.a.:17).

Gereformeerde teologie gaan van die standpunt uit dat God die Bybel op ' $n$ organiese manier geïnspireer het. Die Bybel is naamlik $100 \%$ deur mense geskryf wat deur die Heilige Gees geïnspireer is. Dit is dus $100 \%$ die Woord van God (Coetzee 1990:19). Die gereformeerde standpunt oor die inspirasie van die Skrif hou in dat die teks van die Bybel soos dit oorgelewer is, nie telkens in 'n nuwe bedeling verander word nie. Die Bybel is nie tydsgebonde nie, maar wel tydsgerig. Dit beteken dat die openbaring telkens in ' $\mathrm{n}$ bepaalde konteks toegepas word. In die postmoderne hermeneutiek bepaal die leser egter wat die teks wil sê (Horton 2000:68) en kan die teks dus telkens verander of herinterpreteer word. Verder is daar geen vaste reëls nie (Janse van Rensburg 2000:2).

Die inspirasie deur die Heilige Gees word in 2 Petrus 1:21 beklemtoon: 'Deur die Heilige Gees gedrywe, het die heilige mense van God gespreek.' Vir Jesus Christus was die Bybel onomstootlik die onfeilbare Woord van God en bind dit die Christen aan die Bybel. Wie die Bybel as die Woord van God verwerp, verwerp Christus as die Saligmaker (Booyens 1980:44). Hierdie opvatting aangaande die gesag van die Skrif word in die protestantse tradisie steeds deur teoloë en kerkgemeenskappe aanvaar (vgl onder andere Van den Brink \& Van der Kooi 2012:484; vgl ook Horton 2011:194 e.v.). Die getuienis aangaande Christus in die Skrif is die getuienis van die Vader self. Dit is God se getuienis wat waar en seker is (Van Genderen \& Velema 2008:62). In artikel 5 van die NGB word dit duidelik gestel dat die grond van geloof geheel in die Bybel lê deur die getuienis van die Heilige Gees (Feenstra 1978:25). Dit is die Heilige Gees wat die 'vonk laat oorspring' van die teks na ons hart toe en daardeur bereik die teks sy doel (Verboom 1999:110). 
Volgens die gereformeerde teologie en hermeneutiese vertrekpunte het geen teoloog die reg om oor die kanonisiteit van die Bybel te besluit nie. Geen mens het die Bybelboeke kanoniek gemaak nie, maar deur die inwerking van die Heilige Gees is alles wat in die Bybel opgeneem moes word, daarin opgeneem en die kerk het dit net erken (Duvenage 1963:24). Die kanonisering moet daarom gesien word as 'n kerklike bevestiging van die reeds aanwesige gesag van die Skrif (Verboom 1999:96, 97). Die Heilige Gees lê in die mens se hart die geloof dat die Bybel God se Woord is (NGB art 5). Die gereformeerde benadering wys daarom die standpunt van die feministiese teologie af.

Die gereformeerde beginsel gaan van die standpunt uit dat die Heilige Gees wat die Skrif geïnspireer het en wat in die hart van die gelowige leef, die eintlike Verklaarder van die Skrif is, in ooreenstemming met die beginsel van kongenialiteit. Die ware verstaan en toepassing van die Woord van God vereis derhalwe ware gemeenskap met die Gees (Coetzee 1990:26). Die Heilige Gees het homself na die inspirasie nie van die Heilige Skrif teruggetrek en dit aan sy lot oorgelaat nie. Inteendeel, die Heilige Gees dra en besiel steeds die Skrif en bring die inhoud daarvan in allerlei vorms tot die hart en gewete van die mens (Van Genderen \& Velema 1992:90, met verwysing na Bavinck 1906:410 e.v.). Feministiese teoloë aanvaar egter uit beginsel nie die Skrifverklaring wat deur 'n man gedoen is nie. Gevolglik aanvaar hulle nie die Skrif as sodanig nie en ook nie dat die Heilige Gees wat die Bybel geïnspireer het, die Woord verklaar nie. In hulle benadering ontbreek die kongenialiteit van die Woord (Coetzee 1990:26).

Dit blyk dat die feministiese teoloë nie die hele Bybel as die ewige en onfeilbare Woord van God beskou nie, want hulle wil dele selekteer wat hulle teologie pas en dit interpreteer om hulle te pas. Hulle beskou die vrou as die skopus van die Skrif en nie die verlossing in Jesus Christus nie. Dit word 'n geslagstryd en dit word uit die oog verloor dat dit eintlik gaan oor wie die wil van God doen of nie doen nie (Num 12).

In die Ou Testament word van bekende beelde en metafore gebruik gemaak om aan lesers die boodskap te bring wat God aan hulle wou verduidelik. Dit was alombekend watter bose en slegte invloed ' $n$ ontroue vrou kon hê en daarom is hierdie beeld gebruik (Aalders 1923:26, 27). Dit gaan hier nie oor geslag of diskriminasie teen die vrou nie, of daaroor dat die man net goed is nie. Dit gaan oor die doel waarvoor die beeld gebruik word, naamlik om dit aan die volk tuis te bring hoe erg hulle ontrouheid (hoerery) aan God is (Noordtzi 1932:250). Die feministiese opvatting veroorsaak dat hulle aan Skrifkritiek skuldig is en nie die Bybel as die Woord van God aanvaar nie (Coetzee 1990:18, 19; Breed et al. 2008:37, 38). Wanneer die gereformeerde hermeneutiese beginsel, waar Skrif met Skrif vergelyk word, reg toegepas word, word die onduideliker uitspraak in die lig van die duideliker uitspraak geïnterpreteer (Coetzee 1990:29, 30).

Van Dijk-Hemmes se interpretasie is dat dit in die Bybel oor bevryding gaan, maar dat daardie bevryding vir die vrou op onderdrukking uitgeloop het (Lam \& Strikwerda 1985:11).
Die vrou moet daarom nou van die sogenaamde manlike onderdrukking bevry word. Gevolglik gaan die skopus van die Skrif, naamlik die kruisiging en opstanding van Christus, verlore (Coetzee 1990:21, 22). As die basiese hermeneutiese reëls gevolg word, is die Skrif sy eie verklaarder en is die inlees van geslag nie nodig nie (Coetzee 1990:27, 28).

\section{Hermeneutiek}

Die hermeneutiek van genoemde teoloë toon besliste trekke van die postmoderne hermeneutiek, veral daarin dat die leser die betekenis van die teks bepaal en dat die teks aangepas moet word om by die betrokke lering te pas. Die Bybel word nie verwerp nie, maar 'n dubbele hermeneutiek word bepleit en die bevrydende, onderdrukte stemme van die vrou binne die teks moet uitgebrei word (Fiorenza 1986:19). Hierdie siening kan slegs op die Bybelteks van toepassing gemaak word indien die geïnspireerde en openbarende karakter van die Skrif nie erken word nie (Coetzee 2010:37). Hierteenoor gaan die gereformeerde hermeneutiek juis uit van die outeurskap van die Heilige Gees. Die Postmodernisme aanvaar nie die gesag van die Woord nie en dus ook nie die gesag van die belydenis nie. Die belydenis het juis daardie gesag omdat dit met die Woord ooreenstem en die kerk teen dwaling en leuen wil beskerm (Coetzee 2010:39).

Reformatoriese Skrifverklaring berus op die beginsel dat die Heilige Skrif homself uitlê (Coetzee 1990:27). Bybeluitsprake oor dieselfde saak moet altyd met mekaar vergelyk word en die leser moet vir leiding van die Heilige Gees bid in die verstaan van die Skrif en nie self na goeddunke besluit oor interpretasies nie.

Raphael (1996:100) bevind dat Fiorenza slegs die konkrete lewenservaring van vroue in ag neem. Sy lokaliseer God se primêre openbaring en genade binne die woman-church, 'n beweging wat die bevryding van vroulike, Christelike selfbekragtiging en mag ten doel het, eerder as die Woorde van die bybelse teks self. Volgens Fiorenza se metode word alle tekste op grond van hulle wettiging van, of weerstand teen patriargale onderdrukking geëvalueer (Raphael 1996:100). Haar hermeneutiek is subjektivisties, want die hermeneutiek word verwerp of aanvaar op grond van die beginsels van die feministiese hermeneutiek.

\section{Bybelse konteks}

Die beswaar teen die androsentriese taal wat in die Bybel gebruik sou word, kan afgewys word. Feministiese teoloë beklemtoon die gebruik van die manlike beelde, byvoorbeeld vader (Deut 32), herder (Ps 23) en koning (Rigt 8:23). Daar is egter ook vroulike beelde, byvoorbeeld 'die God wat jou in die wêreld gebring het' (Deut 32:18) en 'nou skree ek soos 'n vrou wat ' $n$ kind in die wêreld bring' (Jes 42:14). In Jesaja 49 word God se ontferming vergelyk met 'n moeder se ontferming oor haar kind en in Lukas 15 met 'n vrou wat 'n muntstuk soek. Daar word ook beelde uit die dierelewe (leeu, beer, arend) en stoflike wêreld (son, fontein, bergvesting) op God toegepas. Christus se wederkoms word met 'n dief vergelyk (Matt 
24:43; 1 Tes 5:2; 1 Pet 3:10; De Bruyn 1993:19; Halkes 1986:62, 63). Die persepsie wat deur sekere feministiese teoloë geskep word, naamlik dat daar net in manlike metafore oor God in die Bybel gepraat word, is ongegrond. Dieselfde geld vir die argument dat die afwesigheid van vroulike voornaamwoorde in die Tien Gebooie daarop kan dui dat vroue daarvan uitgesluit word. Volgens die gereformeerde teologie mag die konteks nie die interpretasie bepaal nie. Breed et al. (2008:51) wys daarop dat elke boek in die Bybel binne die sosiale en politieke werklikhede van daardie betrokke era ontstaan het. Nogtans moet die tersaaklike kultuurhistoriese gegewens wat die Bybel self voorsien, vir interpretasie in ag geneem word en met ' $n$ aanvulling uit ander antieke bronne. Die Woord van God hou verband met die tyd en situasie waarin dit gespreek is, maar is nie aan daardie tyd gebind nie. Die Bybel is naamlik nooit tydsgebonde nie, maar altyd tydsgerig (Coetzee1990:30).

Brenner en Van Dijk-Hemmes oordeel dat sekere dele uit Spreuke deur vroue geskryf is bloot omdat dit so klink, sonder dat hulle enige bewyse daarvoor het. Vir hulle hang die manlikheid of vroulikheid van die teks af van die geslag van die leser, daarom hou hulle hulle besig met die genderbepaling van tekste. Hierdie teologie is nie op die Woord van God geskoei nie, want man en vrou is voor God gelyk - sonder onderskeid. Hoewel daar 'n onderskeid is in die rolle wat mans en vroue het, is hierdie rolle ook gelykwaardig voor God.

\section{Gevolgtrekking}

Uit hierdie artikel en die gereformeerde beoordeling van die onderwerp, is dit duidelik dat daar onversoenbare verskille is tussen die eksponente van die feministiese teologie, Postmodernisme en teoloë met raakpunte aan hierdie teologieë aan die een kant, en die gereformeerde teologie aan die ander kant.

As gevolg van 'n bepaalde Skrifbeskouing word in die feministiese teologie groter vertroue in die eie gevoelens en ervarings as in die Woord van God geplaas. Volgens Dieperink (1987:32-33) verwerp die feministe die Bybel as 'n seksistiese boek wat deur mans geskryf is. Alhoewel God mans geroep het om sy boodskap uit te dra, was dit egter nie die mans se boodskap nie, maar God se boodskap.

Daar is baie gevare verbonde aan die siening van die feministiese teoloë, byvoorbeeld die gevaar van subjektivisme wat ook by die Postmodernisme voorkom. Indien die leser die betekenis van die teks bepaal, sal elke leser sy eie voorkeur daaraan gee, sodat die ware betekenis van die Bybel totaal verlore gaan.

Wat die relativisme betref, is die gevaar dat die goddelike gesag van die Bybel afgeskaal word en die menslike karakter daarvan ten koste van die goddelike beklemtoon word. Die Heilige Gees as eerste skrywer van die Bybel word dan geminimaliseer (Jordaan 1991:8). Vir die gereformeerde teologie wat aanvaar dat die hele Skrif deur die Heilige Gees geïnspireer is, is dit ' $n$ onaanvaarbare aanname, omdat dit mense op 'n dwaalweg kan bring.

By die voltooiing van hierdie navorsing is dit duidelik dat daar onversoenbare verskille tussen die gereformeerde teologie en die feministiese teologie bestaan. In hierdie artikel word juis daarop gefokus. Hierdie verskille is sodanig dat daar nie in die lig van die Skrif en die skrifgefundeerde gereformeerde dogmatiek en die belydenisskrifte van ' $n$ feministiese teologie binne die reformatoriese tradisie gepraat kan word nie. Wat die Skrifbeskouing betref, kan die gereformeerde teologie hom nie met die standpunte vereenselwig wat deur die feministiese teologie gehuldig word nie. In die huidige postmoderne milieu is dit noodsaaklik dat 'n Skrifgetroue teologie aangehang word wat die toets van die tyd deurstaan het. In die reformatoriese teologie word die drie-enige God as die enige Here aanvaar soos Hy Hom in sy Woord openbaar. Die Bybel word as die ewige, altydgeldende Woord van God aanvaar en geen mens mag daarvan iets wegneem of iets byvoeg nie.

\section{Erkenning Mededingende belange}

Die outeurs verklaar dat hulle geen finansiële of persoonlike verbintenis het met enige party wat hulle nadelig kon beïnvloed het in die skryf van hierdie artikel nie.

\section{Outeursbydrae}

A.E.S. (Noordwes-Universiteit) en C.F.S.C. (NoordwesUniversiteit) het gelyke bydraes gelewer tot die navorsing en skryf van hierdie artikel.

\section{Literatuurverwysings}

Aalders, G.C.H., 1923, Korten verklaring der Heilige Schrift: De profeet Jeremia, Kok, Kampen.

Adam, A.K.M., 1995, What is post modern biblical criticism?, Fortress, Minneapolis.

Bal, M., 1993, 'Foreword', in A. Brenner \& F. van Dijk-Hemmes, On gendering texts: Female and male voices in the Hebrew Bible, p. ix, Brill, Leiden.

Bavinck, H., 1906, Gereformeerde dogmatiek, Bos, Kampen.

Bekkenkamp, J., Droës, F., Korte, A. \& Papavoine, M. (eds.), 1989, Proeven van vrouenstudies theologie, DI. 1, Ilmo Research Publication, Utrecht.

Berkouwer, G. C., s.a., Het probleem der Schrifkritiek, Kok, Kampen.

Booyens, M.J., 1980, Ons glo en bely, Calvyn Jubileum Boekefonds, Noordbrug.

Breed, D.G., Van Rensburg, F.J. \& Jordaan, G.J.C., 2008, Manlik en vroulik in die kerk, Potchefstroom Teologiese Publikasies, Potchefstroom.

Brenner, A., 1993a, 'Introduction', in A. Brenner \& F. Van Dijk-Hemmes, On gendering texts: Female and male voices in the Hebrew Bible, pp. 1-13, Brill, Leiden.

Brenner, A., 1993b, 'Proverb 1-9: An F Voice?' in A. Brenner \& F. Van Dijk-Hemmes, On gendering texts: Female and male voices in the Hebrew Bible, pp. 114-130, Brill, Leiden.

Brenner, A. (ed.), 1996, A feminist companion to the Hebrew Bible in the New Testament, Sheffield Academic Press, Sheffield.

Brenner, A., 2004a, 'Introduction', in A. Brenner (ed.), The feminist companion to the latter prophets, pp. 21-37, Clark International, London. PMid:14971419

Brenner, A., 2004b, 'On prophetic propaganda and the politics of "Love": The case of Jermiah,' in A. Brenner (ed.), The feminist companion to the latter prophets, pp. 256-274, Clark International, London.

Brenner, A. \& Fontaine, C. (eds.), 1997, A feminist companion to reading the Bible: Approaches, methods and strategies, Sheffield Academic Press, Sheffield.

Brenner, A. \& Van Dijk-Hemmes, F., 1993, On gendering texts: Female and male voices in the Hebrew Bible, Brill, Leiden.

Buitink-Heijblom, M.A., 1992, Feminisme: Een bijbels-kritische benadering, Kok Voorhoeve, Kampen.

Calvyn, J., 1967, Die 'Institusie' van Calvyn, Opnuut in Afrikaans vertaal en verkort weergegee deur A. Duvenage, Pro Rege Pers, Potchefstroom. 
Clifford, A.M., 2001, Introducing feminist theology, Maryknoll, New York.

Coetzee, C.F.C., 2010, 'Belydenisgebondenheid in 'n postmoderne era', In die Skriflig 44(1), 27-45. http://dx.doi.org/10.4102/ids.v44i1.135

Coetzee, J.C., 1990, 'Die Skrif en die wetenskap: Hermeneutiese reëls', in L. Floor \& J.C. Coetzee, Die skrif en wetenskap, pp. 5-30, PU vir CHO, Potchefstroom.

Daly, M., 1983, Voorbij God de Vader: Op wegnaareen feministische bevrijdingsfilosofie, De Horstink, Amersfoort.

De Bruyn, P.J., 1993, Die feministiese teologie, PU vir CHO, Potchefstroom. (Dept. Sentrale Publikasies, Diktaat nr. D272/93).

Dieperink, M., 1987, Vrouwen op zoek naar God, Voorhoewe, Den Haag.

Duvenage, B., 1963, Hoofpunte van die gereformeerde geloofsleer, Pro Rege Pers, Potchefstroom.

Erickson, M.J., 2001, Escaping Eden: The promise and perils of Postmodernism - Truth or consequences, InterVarsity, Illinois.

Feenstra, J.G., 1950, Onze geloofsbelijdenis, Kok, Kampen.

Feenstra, J.G., 1978, Leer en lewe, vert. M.T.S. Zeeman, Sacum, Bloemfontein.

Fiorenza, E.S., 1979, 'Word, spirit and power: Women in early Christian communities' in R.R. Ruether \& S. McLaughlan, Women of spirit: Female leadership in the Jewish and Christian traditions, pp. 29-70, Simon \& Schuster, New York.

Fiorenza, E.S., 1983-1994, In memory of her: A feminist theological reconstruction of Christian origins, SCM, London.

Fiorenza, E.S., 1985, Wisdom ways: Introducing feminist biblical interpretation, Orbis books, New York.

Fiorenza, E.S., 1986, Geen stenen voor brood: De uitdaging van de feministische Bijbelinterpretatie, Gooi \& Sticht, Hilversum.

Fiorenza, E.S., 1992, But she said: Feminist practices of biblical interpretation, Beacon, Boston.

Fiorenza, E.S., 1996, 'Feminist theologies in different contexts: Introduction', in E.S. Fiorenza \& M.S. Copeland (eds.), Feminist theologies in different contexts, pp. viiix, CM Press, London.

Fiorenza, E.S., 1999, Rhetoric and ethic: The politics of biblical studies, Fortress, Minneapolis.

Fiorenza, E.S. (ed.), 2000, Searching the Scriptures: A feminist introduction, Vol. 1, 2nd edn. The Crossroad Publishing, New York.

Fiorenza, E.S., 2001, Jesus and the politics of interpretation, Continuum, New York.

Fiorenza, E.S., 2010, 'Rethinking the educational practices of biblical doctoral studies', in E.S. Fiorenza \& K.H. Richards (eds.), Rethinking the educational practices of biblical doctoral studies, pp. 373-393, Society of Biblical Literature, Atlanta.

Halkes, C.J.M., 1984, Zoekend naar wat verloren ging: Enkele aansetten voor een feministische theologie, Ten Have, Baarn.

Halkes, C.J.M., 1986, Met Mirjam is het begonnen: Opstandige vrouwen op zoek naar hun geloof, Kok, Kampen.

Horton, M.S., 2000, A confessing theology for postmodern times, Crossway Books, Illinois.

Horton, M., 2011, The Christian faith: A systematic theology for pilgrims on the way, Zondervan, Grand Rapids.
Janse van Rensburg, J., 2000, The paradigm shift, Van Schaik, Pretoria.

Jordaan, G.J.C., 1991, 'Skrifbeskouing: Deurslaggewende faktore by Skrifverklaring', PU vir CHO, Potchefstroom, PU vir CHO, Potchefstroom. (Wetenskaplike bydraes van die PU vir CHO: Inougurele rede $\mathrm{nr}$. 125).

Kassian, M.A., 1992, The feminist gospel, Crossway Books, Illinois.

Lam, H. \& Strikwerda, S., 1985, Leer mij de vrouen kennen, Boekencentrum, 's Gravenhage.

Landman, C., 1989, 'Kom ons maak 'n ketter', Theologia Evangelica 38-40,

Landman, C. \& Van der Watt, J., 2003, 'Openbaring', in C. Landman (red.), Leefstylbybel vir vroue, pp. 1676-1708, Lux Verbi.BM, Paarl.

Noordtzij, A., 1932, Korte verklaring der Heilige Schrift: De profeet Ezechiël, Kok, Kampen.

Oddie, W., 1984, What will happen to God? Ignatius, San Francisco.

Raphael, M., 1996, 'Hermeneutics from a feminist perspective', in L. Isherwood \& D. McEwan (eds.), An A-Z of feminist theology, pp. 99-102, Academic Press, Sheffield.

Ruether, R.R., 2002, 'The emergence of Christian feminist theology', in S.F. Parsons (ed.), The Cambridge companion to feminist theology, pp. 3-22, University of Cambridge Press, Cambridge. http://dx.doi.org/10.1017/CCOL052166327X.001

Russell, L.M. (ed.), 1985, Feminist interpretation of the Bible, Westminster Press, Philadelphia.

Russell, L.M., 1987, Household of freedom: Authority in feminist theology, Westminster Press, Philadelphia.

Schwertley, B.M., s.a., Sola Scriptura and the regulative principle of worship, reformed witness, Southfield, Michigan.

Swart, A.E., 2009, 'Die ooreenkomste tussen die Skrif- en godsbeskouing van enkele internasionale feministiese teoloë en die van teoloë in Suid-Afrika,' PhD-proefskrif, Fakulteit Teologie, North-West University.

Van den Brink, G. \& Van der Kooi, C., 2012, Christelijke dogmatiek, Boekencentrum, Zoetermeer

Van Dijk-Hemmes, F., 1993, 'Traces of women's texts in the Hebrew Bible', in A. Brenner \& F. van Dijk-Hemmes, On gendering texts: Female and male voices in the Hebrew Bible, pp. 17-109, Brill, Leiden.

Van Dijk-Hemmes, F., 1994, 'Toward a Women's Studies Research Program in the Faculty of Theology, Utrecht University', in F. Van Dijk-Hemmes \& A. Brenner (eds.), Reflections on theology and gender, pp. 87-88, Kok Pharos Publishing House, Kampen.

Van Dijk-Hemmes, F., 2004, 'The metaphorization of woman in prophetic speech: An analysis of Ezekiel 23', in A. Brenner (ed.), The feminist companion to the latter prophets, pp. 244-255, Clark International, London.

Van Genderen, J. \& Velema, W.H., 1992, Beknopte gereformeerde dogmatiek, Kok, Kampen.

Van Genderen, J. \& Velema, W.H., 2008, Concise reformed dogmatics, Kok, Kampen.

Van Henten, J.W., 1994, 'Judith as a female Moses: Judith 7-13 in the light of Exodus 17, Numbers 20 and Deuteronomy 33:8-11', in F. Van Dijk-Hemmes \& A. Brenner (eds.), Reflections on theology \& gender, pp. 33-48, Kok Pharos Publishing House, Kampen.

Verboom, W., 1999, Kostbaar belijden: De theologie van de Nederlandse Geloofsbelijdenis, Boekencentrum, Zoetermeer. PMCid:PMC96892 